\title{
ASTROCYTIC AND MICROGLIAL RESPONSE AND HISTOPATHOLOGICAL CHANGES IN THE BRAIN OF HORSES WITH EXPERIMENTAL CHRONIC Trypanosoma evansi INFECTION
}

\author{
Karen Regina LEMOS(1), Luiz Carlos MARQUES(2), Lucia Padilha Cury Thomaz AQUINO(3), Antonio Carlos ALESSI(3) \& Rosangela Zacarias ZACARIAS(3)
}

\begin{abstract}
SUMMARY
This study aimed to characterize astrocytic and microglial response in the central nervous system (CNS) of equines experimentally infected with $T$. evansi. The experimental group comprised males and females with various degrees of crossbreeding, ages between four and seven years. The animals were inoculated intravenously with $10^{6}$ trypomastigotes of $T$. evansi originally isolated from a naturally infected dog. All equines inoculated with T. evansi were observed until they presented symptoms of CNS disturbance, characterized by motor incoordination of the pelvic limbs, which occurred 67 days after inoculation (DAI) and 124 DAI. The animals in the control group did not present any clinical symptom and were observed up to the $125^{\text {th }}$ DAI. For this purpose the HE histochemical stain and the avidin biotin peroxidase method was used. Lesions in the CNS of experimentally infected horses were those of a wide spread non suppurative meningoencephalomyelitis. The severity of lesions varied in different parts of the nervous system, reflecting an irregular distribution of inflammatory vascular changes. The infiltration of mononuclear cells was associated with anisomorphic gliosis and reactive microglia was identified. The intensity of the astrocytic response in the CNS of the equines infected by $T$. evansi characterizes the importance of the performance of these cells in this trypanosomiasis. The characteristic gliosis observed in the animals in this experiment suggests the ability of these cells as mediators of immune response. The parasite, T. evansi, was not identified in the nervous tissues.
\end{abstract}

KEYWORDS: Trypanosoma evansi; Trypanosomiasis; MHC type II; Astrocytes; Microglia.

\section{INTRODUCTION}

African trypanosomes are protozoans that cause diseases in humans and animals ${ }^{33}$. T. evansi is the most widely distributed of all species of trypanosome, and has the greatest economical impact on mammals, particularly on the domestic ones ${ }^{4,33,34,35,41,42}$.

It causes a disease of subacute or chronic course known as "Mal das Cadeiras", characterized mainly by ataxia of the pelvic limbs ${ }^{15,31}$. It brings about impaired locomotion associated to central nervous system lesions $(\mathrm{CNS})^{36}$. In the advanced phases of the evolution of equine experimental trypanosomiasis, weakness of the pelvic limbs and impaired locomotion were observed ${ }^{31}$, besides walking in circles, dysmetria and stiff neck, which are symptoms attributed to myositis, meningomyelitis, encephalitis and plexochoroiditis ${ }^{9,31}$.

The basic lesions in the tissues of animals infected by T. evansi are inflammatory ${ }^{7,23,31,32}$ and are characterized by perivascular cuffing of inflammatory cells, obstruction of capillaries and veins, besides neuronal destruction and demyelinization foci at various degrees ${ }^{3,21}$.

Cell infiltrates are of fundamental importance in the pathogenesis of infectious diseases of the CNS. Specific mechanisms of leukocyte recruitment are required in the infectious encephalitis because the entrance of immune cells is normally limited by the presence of the bloodbrain barrier (BBB), and also because of the complex structure of the endothelial cells, microglia and astrocytes ${ }^{10,32}$.

Microglia and astrocytes represent highly reactive CNS cell populations, which respond to inflammatory and infectious stimuli by regulating molecules implicated in the control of the immune reaction ${ }^{13}$. Microglia cells play the main role in CNS immune vigilance ${ }^{26}$. KREUTZBERG $^{25}$ stated that microglia is the CNS sensor of pathological events, as it is activated in the initial stages of responses to injuries, preceding reactions of other CNS cells. Besides the classical response repertoire, with migration to the injury site, functional, morphological and immune phenotypic changes, the activated microglia can act as cytotoxic cells ${ }^{17,18,32}$. The synergic effects of microglia and astrocytes are necessary for tissue repair after lesions, and they involve the control of the BBB, the entrance of blood cells, removal of proinflammatory cytokines and their regulation ${ }^{32}$.

The purpose of this study was to evaluate, by immunohistochemistry, cell immune response through the reactivity of

(1) Departamento de Medicina Veterinária, UNICENTRO, Guarapuava, PR, Brasil

(2) Departamento de Clínica Médica e Cirurgia, FCAV-UNESP, Jaboticabal, SP, Brasil

(3) Departamento de Patologia veterinária, FCAV-UNESP, Jaboticabal, SP, Brasil.

Correspondence to: Karen R. Lemos, DEVET, UNICENTRO, Rua Simeão Camargo Varela de Sá 03, Guarapuava, PR, Brasil. E-mail: krlemos@yahoo.com.br 


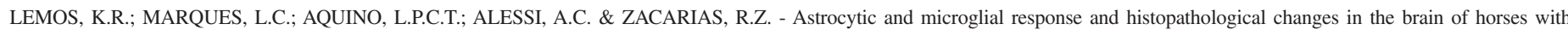
experimental chronic Trypanosoma evansi infection. Rev. Inst. Med. trop. S. Paulo, 50(4): 243-249, 2008.

astrocytes and microglia in the CNS of equines experimentally infected by T. evansi.

\section{MATERIAL AND METHODS}

Animals: The study was conducted with material from research developed by MARQUES ${ }^{31}$ at the Veterinary Hospital of Faculdade de Ciências Agrárias e Veterinárias of UNESP, Jaboticabal, SP, Brazil. Six CNS came from equines experimentally infected with T. evansi (equines 01, 02, 03, 04, 05 and 06). Three clinically healthy equines constituted the control group. The experimental group comprised males and females with various degrees of crossbreeding, and ages between four and seven years. The animals were inoculated intravenously with $10^{6}$ trypomastigotes of $T$. evansi originally isolated from a naturally infected dog. All equines inoculated with T. evansi were observed until they presented symptoms of CNS disturbance, characterized by motor incoordination of the pelvic limbs, which occurred 67 days after inoculation (DAI) in equine 03, 77 DAI in equines 04 and 06, 78 DAI in equines 01 and 02 , and $124 \mathrm{DAI}$ in equine 05 . The animals in the control group (equines 07, 08 and 09) did not present any clinical symptom and were observed up to the $125^{\text {th }}$ DAI. Animals were sedated with acepromazine $1 \%$ at $0.1 \mathrm{mg} / \mathrm{kg}$, and after 10 minutes, by guaifenesine at $100 \mathrm{mg} / \mathrm{kg}$, followed by a barbituric general anesthesia with thiopental at $15 \mathrm{mg} / \mathrm{kg}$ and euthanized as indicated by THURMON $^{46}$.

Tissue processing: After sagittal section of the skull of the animals, the CNS was carefully removed and placed in a $10 \%$ buffered formalin solution, $\mathrm{pH}$ 7.2. The following CNS areas were predetermined and analyzed: (1) subcortical white matter; (2) cerebral cortex; (3) thalamus; (4) hippocampal formation; (5) bulb section; (6) cerebellum; (7) sections of the spinal cord of the cervical, thoracic and lumbar areas. The material was processed for paraffin embedding, cut into $5 \mu \mathrm{m}$ thicksection and sections were initially stained with hematoxylin-eosin method.

Immunohistochemical evaluations of the CNS equines: The immunohistochemical method used was the avidin-biotin peroxidase complex (ABC). The protocol of the immunohistochemical reactions was initiated by the deparaffinization in xylene and re-hydration in alcohol. Endogenous peroxidase was blocked at room temperature with specific blocker Dako S2001; the material was then incubated for 30 minutes (PBS-BSA 5\%) to block unspecific proteins. Two washes with Tris HCL added with Tween 20 were carried out between all incubations. The material was revealed with DAB (diaminobenzidine) for five minutes (Reagent 54-10-00 KPL) and counterstained with Harris hematoxylin 1:2.

Anti-HLA antibody (Clone TaL.1B5) (Dako M0746) was used to demonstrate MHC II antigens, diluted at 1:200, for 12-18 h. The sections were pre-treated with target retrieval solution (Dako-S1699), diluted at $1: 10$, for 30 minutes in a steam pot $\left(95^{\circ} \mathrm{C}\right)$ and later incubated with goat anti-mouse biotinylated antibody (Dako E0433), diluted at 1:200, for 45 minutes.

Enzymatic process of antigenic reactivation was used to demonstrate astrocytes, using Pronase (Dako S2013) during 15 minutes, followed by the application of anti-GFAP antibody (Dako ZO334) diluted at 1:300 for 12-18 h. Goat anti-rabbit antibody (Dako E0433) was used as binding antibody diluted at 1:200 for 45 minutes.

Astrocytic densitometry was measured with the use of a 0.0625 $\mathrm{mm}^{2}$ area integrator lens coupled to a $12.5 \mathrm{x}$ eyepiece, with a $40 \mathrm{x}$ objective lens. Pro-image Plus software connected to a BX50 Olympus microscope, standardized for reading with a $40 \mathrm{X}$ objective and intermediate lens 1 was used for morphometry of astrocyte nuclei and characterization of astrocyte hypertrophy.

\section{RESULTS}

Histopathological evaluation of the CNS of the equine: The histopathological alterations observed in the equines inoculated with T. evansi were predominantly inflammatory infiltrates, ranging from discreet to intense, meningeal infiltrates and perivascular cuffs in the cerebellar cortex, composed of mononuclear cells (lymphocytes, plasmocytes, and lymphoblasts) associated to the reactive microglia. Gemistocytes and axonal spheroids were observed in the cortical region of the white matter of the brains, which characterize a degenerative process. In the gray matter, areas of neuronal necrosis were evidenced, which were characterized by chromatolysis, satellitosis and neuronophagia. The parasite, T. evansi, was not identified in the nervous tissue.

Immunohistochemical reactions: In the control equines, astrocytes presented their characteristic morphology, with thin and poorly ramified processes, positive staining for GFAP, and small nuclei. When comparing them with the inoculated animals, these were observed to present increased astrocyte density. In the equines experimentally infected with $T$. evansi, intense glial immunoreactivity related to the submeningeal and perivascular inflammatory infiltrates was observed in the region of the external limiting glial membrane. In the spinal cord, cell nuclei were hardly visualized, however, their intensively reactive processes were identified around the myelinated axons.

In the cerebellar region, intense astrocytic reactivity, characterized by hypertrophic cells and increase in cell density, was observed (Fig. 1 $\mathrm{A}$ and $\mathrm{E}$ ). Increase in volume of cell bodies and significant thickening of astrocyte processes, with intense immunoreactivity to GFAP, were also well characterized in the areas of the Purkinje cells of the cerebella (Fig. 1 B).

Increase in astrocyte density and volume of cell bodies, besides thick processes of astrocytes around blood vessels, were well characterized in the region of the thalamus (Fig. 1 C). In the cortex, the immunoreactive astrocytes were distributed in the parenchyma and in the proximity of blood vessels (Fig. 1 D). Numerous binucleate cells reactive to GFAP were observed in the subcortical cerebellar white matter, near the neurons or dissociated from them (Fig. 1 F). GFAP expression was also visualized in a diffuse form and not only associated with vascular or degenerative lesions in glial cells of extralesional regions.

The microglial cells of the equines of the control group visualized with the anti-MHC antibody (Tal1B5 clone) were at rest, with characteristic round-shaped, their cytoplasm and processes stained brown (Fig. 2 A). In the equines inoculated with $T$. evansi the process 


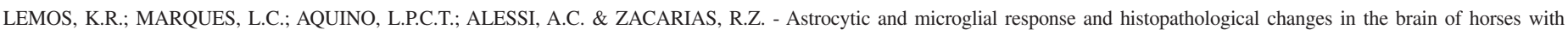
experimental chronic Trypanosoma evansi infection. Rev. Inst. Med. trop. S. Paulo, 50(4): 243-249, 2008.

of activation of those cells was noticed by their longer form (rod cells), with fusiform aspect and thickening of the processes, which were immunoreactive to the antibody used (Fig. 2 B and C). Cells in phagocytic phase ("gitter cells") were observed in the neuropil of the equines inoculated with $T$. evansi, generally associated with degenerative or inflammatory processes.
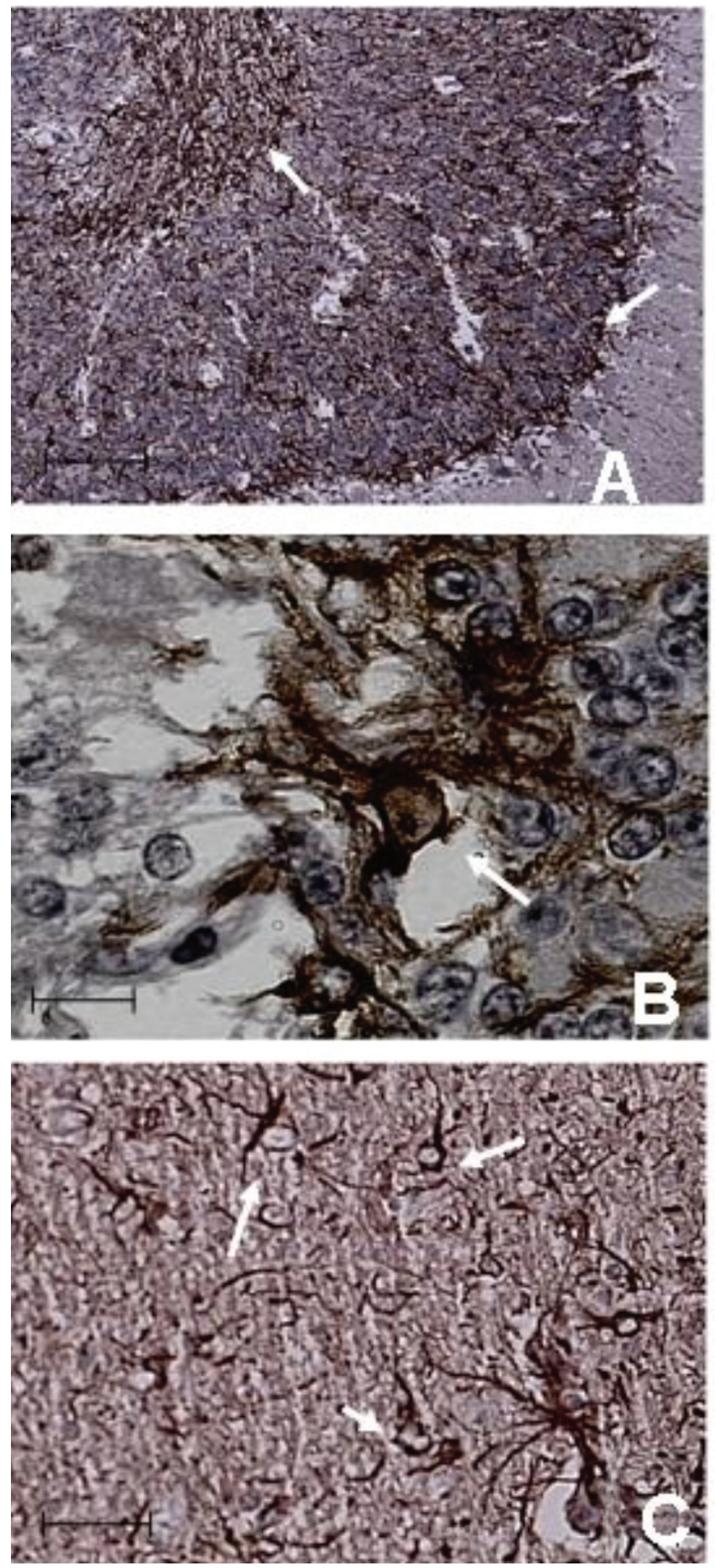

The ependymal cells that cover brain ventricles also presented subliminal immunoreactivity to the anti-MHC II marker in animals of the control group. In the animals inoculated with T. evansi, those cells presented more expressive immunological reaction (Fig. 2 D).
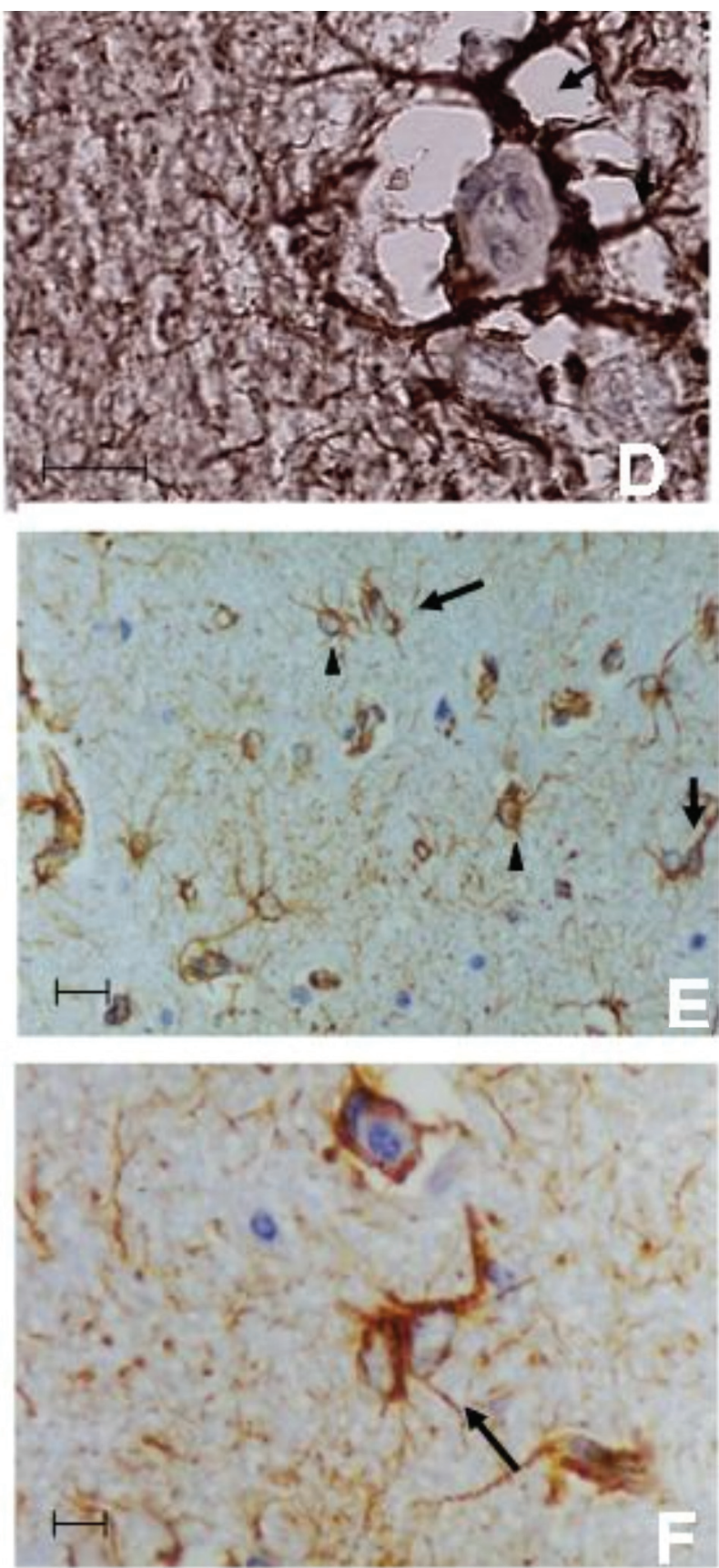

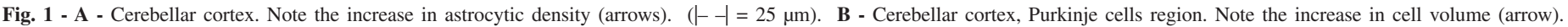

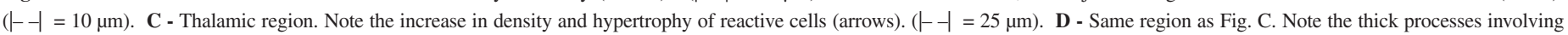

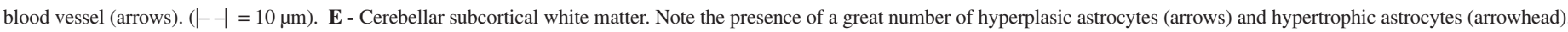
$(|--|=25 \mu \mathrm{m})$. F - Cerebral cortex. Binucleate astrocytes near neurons. $(|--|=10 \mu \mathrm{m})$. ABC method. Anti-GFAP antibody. Equines experimentally inoculated with $T$. evansi. 

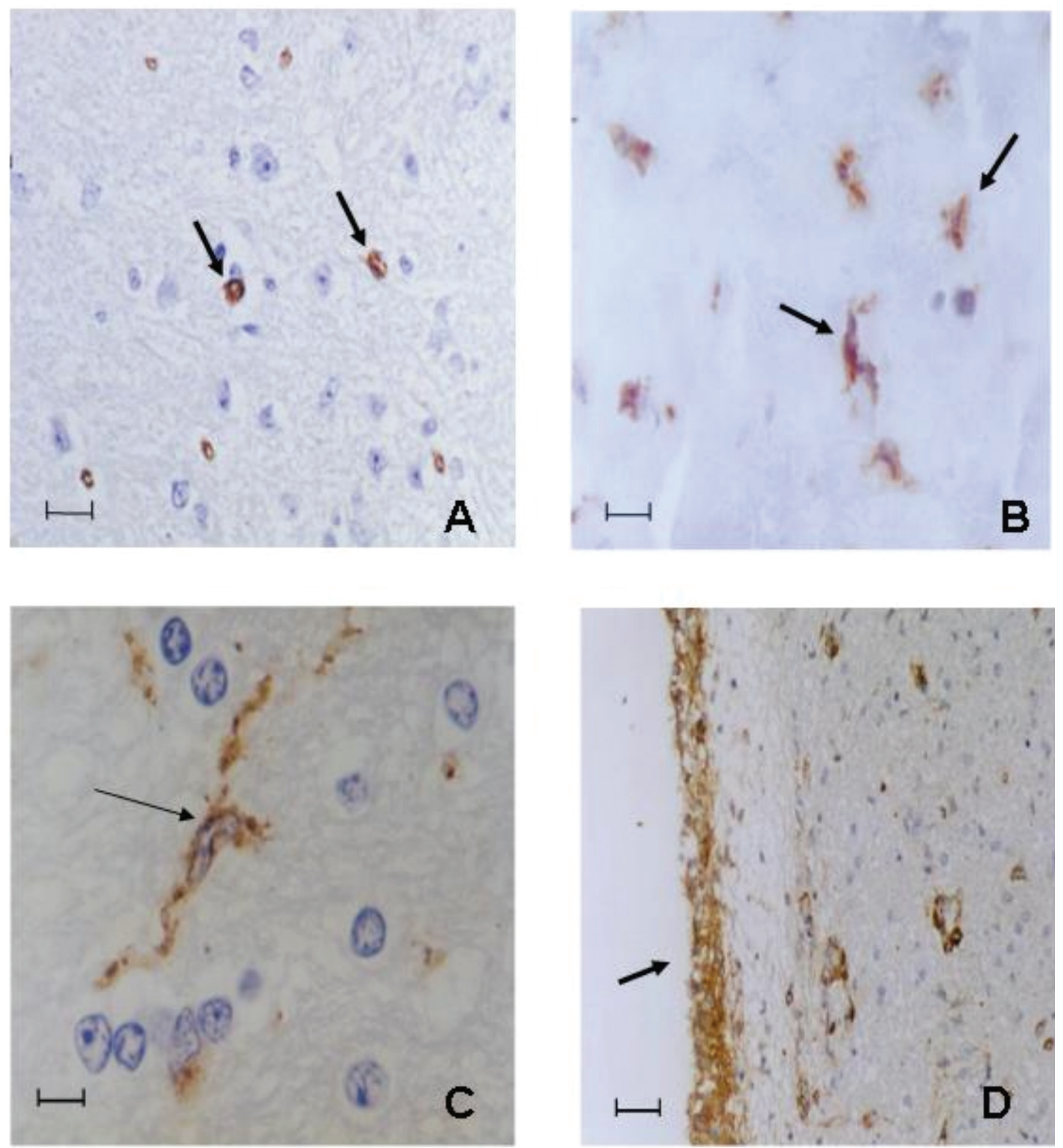

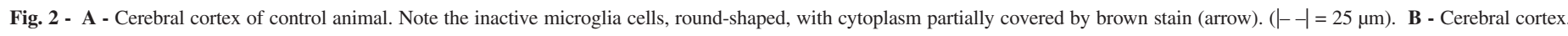

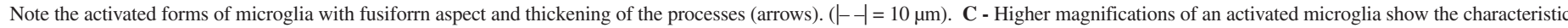

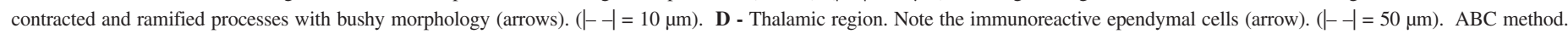
Anti-HLA antibodies. Equines experimentally inoculated with T. evansi.

\section{DISCUSSION}

Experimental evidence suggests that in a response to invasion, the CNS may create its own defense system through the resident cells, the microglia and astrocytes. Both cells may modulate the function of hematogenous cells, establishing integration between the CNS resident cells and immune system cells ${ }^{8,20,48}$. The intensity of the astrocytic response in the CNS of the equines infected by $T$. evansi characterizes the importance of the performance of these cells in this trypanosomiasis and demonstrates that their strategic positioning in the blood cerebral 
parenchyma interface influences the functioning of the BBB, as well as its activity in the $\mathrm{CNS}^{14}$. This astrocytic response determines alterations in the cell-cell recognition/contact properties ${ }^{6,12,38}$.

Although the lesion is local, the GFAP immunoreactivity increase response is disseminated, which evidences communication between those cells ${ }^{28}$. The pattern of glial alterations observed in this experiment was described in African trypanosomiasis of rodents ${ }^{1}$ and humans ${ }^{37}$. The alterations in GFAP expression visualized in this experiment, which were diffuse and not only associated with vascular or degenerative lesions in glial cells of extralesional regions, confirms that the initial astrocytic response to injuries modifies pre-existent cell properties and determines a complex network of phenotype, structural and metabolic alterations, as suggested by LINDSAY ${ }^{30}$.

The alterations in reactive gliosis are directly associated to the chronicity of this infection, because, if astrocytes are not initially destroyed by ischemia or any other lesional process, astrocytosis occurs, defined by GRAHAM ${ }^{19}$ as hypertrophy and hyperplasia of these cells, with an increase in GFAP expression. In mice infected by T. brucei, immunohistochemical studies with GFAP demonstrated the occurrence of astrocytosis directly related to time of infection: in its initial phase it occurred in the white matter, and posteriorly, in the neuropil, in a diffuse form ${ }^{24}$. Binucleate cells, reactive to GFAP, near or associated to neurons suggest that astrocytes are capable of splitting and that these alterations represent the final result of neuronal destruction ${ }^{6}$, in an attempt to restore neuronal volume ${ }^{28}$. Double-dye methods have shown cells with characteristics of astrocytes undergoing mitosis after injuries $^{28,29,36,37}$. Alterations in GFAP expression were detectable, but their functional significance is uncertain; an increase in its expression may be related to an increase in CNS structural integrity. NORTON et $a l .{ }^{38}$ define a positive correlation between the amount of GFAP and the intensity of GFAP immunocytochemical pattern in the CNS; however, they do not explain the primary function of this pattern.

The intensity of the astrocytic response in the CNS of the equines infected by $T$. evansi characterizes the importance of the performance of these cells in this trypanosomiasis and demonstrates that their strategic positioning in the interface between blood and cerebral parenchyma influences cell entrance via blood, as well as its activity in the $\mathrm{CNS}^{14}$.

Microglial cells of the equines in the control group were at rest, with their characteristic bipolar shape and cytoplasm and processes partially stained in brown, which reinforces the observations of KREUTZBERG $^{25}$ that the microglia at rest shows a subliminal immunophenotype adapted to the specialized microenvironment of the CNS. Nonetheless, its ability to promptly respond to the variety of molecular signals suggests that its apparent rest represents an alert state to detect the alterations in its extracellular environment. This responsiveness of the microglia was verified in the CNS of the equines inoculated with $T$. evansi by the presence of longer forms, with fusiform aspect and with thickening of the processes, which were immunoreactive to anti-MHC II antibody, what characterizes a phase in the process of activation of these cells. Microglia activation presents a stereotyped pattern, regardless the cause of the lesion, with proliferation and migration to the lesion site and morphofunctional and immunophenotypic alterations ${ }^{25}$.
Phenotypical analysis of cells limited to the chronic phase does not allow definite conclusions about the onset of the immunological response to the agent; however, it is known that the activation of microglia precedes reactions of other cell types in the brain ${ }^{25}$.

Gitter cells were observed in the cortical region of the CNS of the inoculated equines, generally associated with inflammatory infiltrates and areas of CNS degeneration. Positive immunemarking in the presence of anti-CMH II antibody reinforces the idea that these cells act as resident macrophages and present morphofunctional characteristics of antigen-presenting cells. Furthermore, it is suggested that microglia originates from the monocytic-macrophagic lineage, which is in accordance with the observations of BARRON ${ }^{5}$ and STREIT et al. . $^{5}$

The activated microglia may induce, through cytokines, the characteristics of adhesivity of the endothelial cells ${ }^{22,32}$. The participation of endothelial cells in this trypanosomiasis was shown by the detection of superexpression of MHC II molecules. Results from in vitro studies suggested astrocytes, microglial and endothelial cells to express MHC-I and II antigens to T lymphocytes under certain conditions $^{32}$. Furthermore, astrocytes act in harmony with endothelial cells, microglia and lymphocytes to regulate the immune response in the $\mathrm{CNS}^{39}$

The way trypanosomes can penetrate the BBB and invade the CNS has not been determined yet, but the liberation of toxic substances by trypanosomes has been suggested to open cell junctions (zonula occludens) of the ependyma ${ }^{27}$. The immunoreactivity to MHC II antibody observed in the ependyma in this experiment suggests the function of the choroid plexus in the response induced by the Trypanosome, or, maybe, the route by which the parasite crosses the hematoencephalic barrier, a fact demonstrated by the presence of trypanosomes in the neuropil, immunohistochemically marked in acute natural infections ${ }^{33}$, but not observed in this chronic experimental infection.

The ability of the microglia to act as antigen-presenting cell, as demonstrated in this experiment, suggests it has a function in the local amplification of the immune response, by the restimulation of $\mathrm{T}$ cells $^{2,11,16,25}$. Although they rarely express MHC II in CNS inflammatory processes, astrocytes produce several mediators that may regulate immune cell function and recruit chemokines, thus elaborating a complex network of interactions among microglia, astrocytes and $\mathrm{T}$ cells that invade the CNS, determining a balance between TH1 and TH2 signals ${ }^{2}$. The characteristic gliosis observed in the animals in this experiment suggests the ability of these cells as mediators of immune response.

This study demonstrated the ability of the microglia to act as antigen presenting cell and its capacity to increase local immune response and evidenced that the number of antigens presenting cells and the density of expression of the class II histocompatibility molecules in the different populations in the CNS may influence the result of the immune response. 


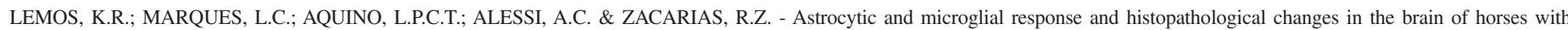
experimental chronic Trypanosoma evansi infection. Rev. Inst. Med. trop. S. Paulo, 50(4): 243-249, 2008.

\section{RESUMO}

Resposta astrocítica e microglial e alterações histopatológicas no sistema nervoso central de eqüinos infectados cronicamente com Trypanosoma evansi

Este estudo objetivou caracterizar a participação astrocítica e microglial no sistema nervoso central (SNC) de eqüinos experimentalmente infectados com $T$. evansi. O grupo experimental foi formado por machos e fêmeas com vários graus de cruzamentos e idade variando entre quatro e sete anos. Os animais foram inoculados com $10^{6}$ tripomastigotas de $T$. evansi, originalmente isolada de um cão infectado naturalmente. Todos os eqüinos inoculados foram observados até o aparecimento dos sintomas neurológicos, caracterizados por incoordenação motora dos membros pélvicos, o qual ocorreu entre 67 e 124 dias após a inoculação (DPI). Os animais do grupo controle não apresentaram sinais clínicos e foram observados até o $125^{\circ}$ DPI. Para este propósito, foram utilizados os métodos histoquímicos (HE) e imunoistoquímicos do complexo avidina-biotina peroxidase (ABC). A lesão no sistema nervoso central (SNC) dos eqüinos infectados com T. evansi foi caracterizada como meningoencefalomielite não supurativa. A gravidade das lesões variou em diferentes segmentos do SNC, refletindo distribuição irregular das alterações vasculares. Infiltrado perivascular e meníngeo foi associado a gliose anisomórfica e microgliose reativa. A intensidade da resposta astrocítica no SNC dos equinos infectados com $T$. evansi caracteriza a importância da performance destas células nas tripanossomíases. A gliose observada nos animais deste experimento sugerem a habilidade destas células como mediadoras da resposta imune. T. evansi não foi identificado no parênquima do SNC.

\section{ACKNOWLEDGEMENTS}

Study conducted with financial grants from Fundação de Amparo à Pesquisa do Estado de São Paulo - FAPESP. Grants Nos. 99/06927-0 (research grant) and 99/06928-6 (doctoral degree scholarship).

\section{REFERENCES}

1. ADAMS, J.H.; HALLER, L.; BOA, F.Y. et al. - Human African trypanosomiasis (T.b. gambiense): a study of 16 fatal cases of sleeping sickness with some observations on acute reactive arsenical encephalopathy. Neuropath. appl. Neurobiol., 12: 81-94, 1986.

2. ALOISI, F.; RIA, F.; PENNA, G. \& ADORINI, L. - Microglia are more efficient than astrocytes in antigen processing and in TH1 but not TH2 cell activation. J. Immunol., 160: 4671-4680, 1998.

3. ANTHOONS, J.A.; VAN MARCK, E.A.; GIGASE, P.L. \& STEVENS, W.J. Immunohistochemical characterization of the mononuclear cells in the brain of the rat with an experimental chronic Trypanosoma brucei gambiense infection. Parasit. Res., 75: 251-256, 1989.

4. AUDU, P.A.; ESIEVO, K.A.; MOHAMMED, G. \& AJANUSI, O.J. - Studies of infectivity and pathogenicity of an isolate of Trypanosoma evansi in Yankasa sheep. Vet. Parasit., 86: 185-190, 1999.

5. BARRON, K.D. - The microglial cell. A historical review. J. neurol. Sci., 134 (suppl.): 57-68, 1995.
6. BIGNAMI, A. \& DAHL, D. - Gliosis. In: HELMUT KETTENMANN, H. \& RANSOM, B.R. Neuroglia. London, Oxford University Press, 1995. p. 843-858.

7. BOERO, J.J. - Parasitosis animales. 3. ed. Buenos Aires, Eudeba, 1974.

8. BRITO JUNIOR, L.C.; CAMPANELLI, A.P.; FIGUEIREDO, F.C.N. \& CUNHA, F.Q. Reactive astrocytes of the pathology of cryptococcal meningoencephalitis. In: INTERNATIONAL MEETING ON IMMUNOREGULATION: INSIGHTS FOR THERAPEUTICS INTERVENTION, Florianópolis, 2000. Abstracts.. Florianópolis, Ed. UNIVALI, 2000. p. 213, ID-27.

9. CADIOLI, F.A. - Infecção experimental em jumento (Equus asinus) com Trypanosoma evansi Steel, 1885 (Sarcomastigophora:Trypanosomatidae). Jaboticabal, 2001. (Dissertação de Mestrado em Clínica Médica Veterinária - Faculdade de Ciências Agrárias e Veterinárias da Universidade Estadual Paulista).

10. DECKERT-SCHLUTER, M.; SCHLUTER, D.; HOF, H.; VIESTLER, O.D. \& LASSMAN, H. - Differential expression of ICAM-1,VCAM-1 and their ligands LFA1,Mac-1, CD43 and MHC-class II antigens in murine Toxoplasma encephalitis: a light microscopic and ultrastructural immunohistochemical study. J. Neuropath. exp. Neurol., 53: 445-468, 1994.

11. De SIMONE R.; GIAMPAOLO, A.; GIOMETTO, B. - The costimulatory molecule B7 is expressed on human microglia in culture and in multiple sclerosis acute lesions. J. Neuropath. exp. Neurol., 54: 175-187, 1995.

12. DONG, Y. \& BENVENISTE, E.N. - Immune function of astrocytes. Glia, 36: 180-190, 2001.

13. EDDLESTON, M. \& MUCKE, L. - Molecular profile of reactive astrocytes: implication for their role in neurologic disease. Neuroscience, 54: 15-36, 1993.

14. FONTANA, A.; FREI, K.; BODMER, S. \& HOFER, E. - Imune-mediated encephalitis: on the role of antigen-presenting cells in brain tissue. Immunol. Rev., 100: 185201, 1987.

15. FRANKE, C.R.; GREINER, M. \& MEHLITZ, D. - Investigations on naturally occurring Trypanosoma evansi infections in horses, cattle, dogs and capybaras (Hydrochaeris hydrochaeris) in Pantanal de Poconé (Mato Grosso, Brazil). Acta trop., 58: 159169,1994 .

16. GEHRMANN, J.; BANATI, R.B.; WIESSNER, C.; HOSSMANN, K.A \& KREUTZBERG, G.W. - Reactive microglia in cerebral ischaemia: an early mediator of tissue damage? Neuropath. appl. Neurobiol., 21: 277-289, 1995.

17. GIULIAN, D. - Microglia and disease of nervous system. Curr. Top. Neurol., 12: 23 $54,1992$.

18. GIULIAN, D. \& ROBERTSON, C. - Inhibition of mononuclear phagocytes reduces ischemic injury in spinal cord. Ann. Neurol., 27: 32-42, 1990.

19. GRAHAM, D.I. - Hypoxia and vascular disorders. In: ADAMS, J.H. \& DUCHEN, L.W., ed. Greenfield's Neuropathology. New York, Oxford University Press, 1992. p. 153-268.

20. HICKEY, W.F.; HSU, B.L. \& KIMURA, H.T. - T cell entry into the central nervous system. J. Neurosci. Res., 28: 254-260, 1991.

21. HOLMES, P.H. - Pathophysiology of parasitic infections. Parasitology, 94 (suppl.), S29-S51, 1987.

22. JANZER, R.C. \& RAFF, M.C. - Astrocytes induce blood-brain barrier properties in endothelial cells. Nature, 325: 253-257, 1987.

23. JUBB, K.V.F. \& HUXTABLE, C.R. - The nervous system. In: JUBB, K.V.F.; KENNEDY, P.C. \& PALMER, N. Pathology of domestic animals. 4. ed. San Diego, Academic Press, 1993. v. 1, p. 267-439. 


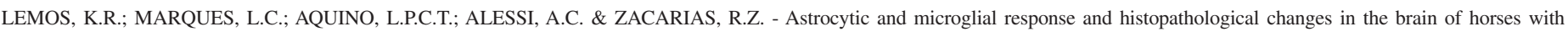
experimental chronic Trypanosoma evansi infection. Rev. Inst. Med. trop. S. Paulo, 50(4): 243-249, 2008.

24. KEITA, M.; BOUTEILlE, B.; ENANGA, B. VALLAT, J.M \& DUMAS, M. Trypanosoma brucei brucei: a long-term model of human African trypanosomiasis in mice, meningo-encephalitis, astrocytosis, and neurological disorders. Exp. Parasit., 85: 183-192, 1997.

25. KREUTZBERG, G.W. - Microglia; a sensor for pathological events in CNS. Trends Neurosci., 19: 312-318, 1996.

26. KREUTZBERG, G.W. \& RAINVICH, G. - The microglial concept. Brain Path., 7: 1231-1233, 1997.

27. LAMBERT, P.H.; BERNEY, M. \& KAZYUMBA, G. - Immune complexes in serum and cerebrospinal fluid in African trypanosomiasis. Correlation with polyclonal B cell activation and with intracerebral immunoglobulin synthesis. J. clin. Invest., 67: 77$85,1981$.

28. LANDIS, D.M.D. - The early reactions of non-neuronal cells to brain injury. Ann. Rev. Neurosci., 17: 133-151, 1994.

29. LATOV, N.; NILAVER, G.; ZIMMERMAN, E.A. et al. - Fibrillary astrocytes proliferate in response to brain injury: a study combining immunoperoxidase technique for glial fibrillary acidic protein and radioautography of tritiated thymidine. Dev. Biol., 72: 381-384, 1979.

30. LINDSAY, M.P. - Reactive gliosis. In: FEDOROFF, S. \& VERNADAKIS, A. Astrocytes: cell Biology and Pathology of astrocytes. New York, Academic Press, 1996. v. 3, p. 231-262.

31. MARQUES, L.C. - Infecção experimental em equinos com Trypanosoma evansi (Steel, 1885) (Sarcomastigophora: Trypanomatidae). Jaboticabal, 1996. (Tese de Livre Docência em Clínica Médica - Faculdade de Ciências Agrárias e Veterinárias da Universidade Estadual Paulista).

32. MERRIL, J.E. \& BENVENISTE, E.N. - Cytokines in inflammatory brain lesions: helpful and harmful. Trends Neurosci., 19: 331-338, 1996.

33. MONZON, C.M.; MANCEBO, O.A. \& ROUX, J.P. - Comparison between six parasitological methods for diagnosis of Trypanosoma evansi in the subtropical area of Argentina. Vet. Parasit., 36: 141-146, 1990.

34. MOREIRA, R.D. \& MACHADO, R.Z. - Identificação e isolamento do Trypanosoma equinum em um cão do Município de Camapuã, M.S. In: ENCONTRO DE PESQUISAS VETERINÁRIAS, 10, Jaboticabal, 1985. Resumos. p. 66.

35. MUÑOZ, K. \& CHÁVEZ, A. - Trypanosoma evansi isolated from Capybara (Hidrocaeris hidrocaeris). Mem. Inst. Oswaldo Cruz, 96: 945-946, 2001.

36. MYIAKE, T.; HATTORI, T.; FUKUDA, M.; KITAMURA, T. \& FUJITA, S. - Quantitative studies on proliferative changes of reactive astrocytes in mouse cerebral cortex. Brain Res., 45: 133-138, 1988.
37. MYIAKE, T.; OKADA, M. \& KITAMURA, T. - Reactive proliferation of astrocytes studied by immunohistochemistry for proliferating cell nuclear antigen. Brain Res., 590: 300-302, 1992.

38. NORTON, W.T.; AQUINO, D.A.; HOZUMI, I.; CHIU, F.C. \& BROSNANC, C.F. Quantitative aspects of reactive gliosis. A review. Neurochem. Res., 17: 877-885, 1992.

39. PENTREATH, V.W.; BAUGH, P.J. \& LAVIN, D.R. - Sleeping sickness and the central nervous system. Onderstep. J. vet. Res., 61: 369-377, 1994.

40. RODRIGUES, A. - Infecção natural por Trypanosoma evansi em eqüinos. Santa Maria, 2006. (Dissertação de Mestrado em Patologia Veterinária - Universidade Federal de Santa Maria)

41. SILVA, R.A.; AROSEMENA, N.A.; HERRERA, H.M., SAHIB, C.A. \& FERREIRA, M.S. - Outbreak of trypanosomosis due to Trypanosoma evansi in horses of Pantanal Mato-grossense, Brazil. Vet. Parasit., 60: 167-171, 1995.

42. SINGH, B.; KALRA, I.S.; GUPTA, M.P. \& NAURIYAL, D.C. - Trypanosoma evansi infection in a dog: seasonal prevalence and chemotherapy. Vet. Parasit., 50: 137$141,1993$.

43. SOODAN, J.S.; SOOD, N.K.; KHAHRA, S.S. et al. - Clinical pathological studies in donkeys experimentally infected with Trypanosoma evansi. Indian An. Sci., 66: 443-448, 1996.

44. STEVENS, D.R. \& MOULTON, J.E. - Experimental meningoencephalitis in Trypanosoma brucei infection of deer mice (Peromyscus maniculatus). A light, immunofluorescent and electron microscopic study. Acta Neuropath., 38: 173-180, 1977.

45. STREIT, W.J.; GRAEBER, M.B. \& KREUTZBERG, G.W. - Functional plasticity of microglia: a review. Glia, 1: 301-307, 1988.

46. THURMON, J.C. - Euthanasia. In: MUIR, W.W. \& HUBBELL, J.A.E. Equine anesthesia. Monitoring and emergency therapy. St Louis, Mosby, 1991. p. 485-495.

47. UCHE, U.E. \& JONES, T.W. - Pathology of experimental Trypanosoma evansi infection in rabbits. J. comp. Path., 106: 299-309, 1992.

48. VASS, K. \& LASSMANN, H. - Intrathecal application of interferon gamma. Progressive appearance of MHC antigens within the rat nervous system. Amer. J. Path., 137: 789-800, 1990 .

Received: 2 July 2007

Accepted: 5 June 2008 